Journal of Engineering Sciences, Assiut University, Vol. 40, No. 4, pp. 969 -987, July 2012

\title{
SHEAR BEHAVIOUR OF HIGH STRENGTH FIBER REINFORCED CONCRETE CORBELS
}

\author{
Atif M. Abdel Hafez ${ }^{1}$, Mohamed M. Ahmed ${ }^{1}$, Hesham Diab $^{2}$ \\ and Ahmed Attia M. Drar ${ }^{3}$ \\ ${ }^{1}$ Associate professor, Civil Engineering Department, Assiut University \\ ${ }^{2}$ Lecturer, Civil Engineering Department, Assiut University \\ ${ }^{3}$ Demonstrator, Civil Engineering Department, Sohag University
}

Email: attya85@yahoo.com,

(Received March 21, 2012 Accepted April 15, 2012)

An experimental study of shear behaviour of high strength reinforcedconcrete corbels with and without fibers was investigated. Seventeen high strength reinforced-concrete corbels were tested. The test variables were steel fiber content (Vf\%), shear span-to-depth ratio (a/d), concrete strength $(\mathrm{fcu})$, area of main steel reinforcement (Asm) and presence of horizontal stirrups. Test results showed that, addition of steel fibers or/and horizontal stirrups improves both shear strength and ductility of the tested corbels, and results in a more ductile failure mode. Test results were compared with shear strength predicted using ACI 38-08 equations and those proposed by other investigators. Comparison between the experimental and the predicted values of shear strengths showed that the model proposed by G. Campione et.al. [1], satisfactory predicted the ultimate load for high strength fiber reinforced-concrete corbels.

KEYWORDS: Fiber reinforced concrete, High-strength concrete, Steel fibers, Shear behavior, Shear strength, Corbels.

\begin{tabular}{|llcl|}
\hline \multicolumn{3}{|c|}{ NOTATION } \\
a/d & shear span-to-depth ratio & $f_{c u}$ & cube compressive strength $\left(\mathrm{N} / \mathrm{mm}^{2}\right)$ \\
$A_{s h}$ & area of horizontal stirrups $\left(\mathrm{mm}^{2}\right)$ & $V_{f} \%$ & steel fibers content \\
$A_{s m}$ & area of main steel reinforcement $\left(\mathrm{mm}^{2}\right)$ & & \\
\hline
\end{tabular}

\section{INTRODUCTION}

Corbels are structural members very commonly used in reinforced concrete structures, particularly in precast structures where their principal function is the transfer of vertical and horizontal forces to principal members. Corbels are structural members characterized by a shear span-to-depth ratio $(a / d)$, generally lower than unity and subjected to concentrated forces as in support zones. For these reasons, they are host zones of the static and geometric discontinuities and the hypothesis assumed for members in flexure that sections remain plane after deformation is not valid in this case. Many studies [1-13] were conducted to determine experimentally and analytically, the strength of such elements when subjected to vertical and horizontal forces, and explained the role of the parameters that influence the performance of corbels, including their shape and dimensions, the type of longitudinal and transverse steel reinforcements, and the strength of concrete. 
Recently, high strength concrete has been increasing used in practice. But high-strength concrete is considered to be a relatively brittle material and has low ductility. In this investigation, the main goal was using steel fibers to convert the brittle characteristic to a ductile one, increases the strength and improves the ductility.

In this research the shear behaviour of high strength corbels with and without steel fiber was studied. The main variables investigated were, steel fibers content $\left(V_{f}\right.$ $\%)$, shear span-to-depth ratio $(a / d)$, concrete strength $\left(f_{c u}\right)$, area of main steel reinforcement $\left(A_{s m}\right)$ and presence of horizontal stirrups.

\section{EXPRERIMENTAL PROGRAM}

\subsection{Test Specimens}

Seventeen $150 \times 150 \times 200 \mathrm{~mm}$ high strength reinforced-concrete corbels, having the geometry and steel reinforcement arrangements shown in Fig 1, were tested. Main bars were bent at the ends with bond length equal to effective depth. Some corbels were reinforced with two horizontal stirrups having a diameter of $6 \mathrm{~mm}$. For all specimens, column segments were reinforced with four deformed bars having $10 \mathrm{~mm}$ diameter and stirrups of $6 \mathrm{~mm}$ diameter placed at a pitch of $100 \mathrm{~mm}$. Details of specimens are given in Table 1.
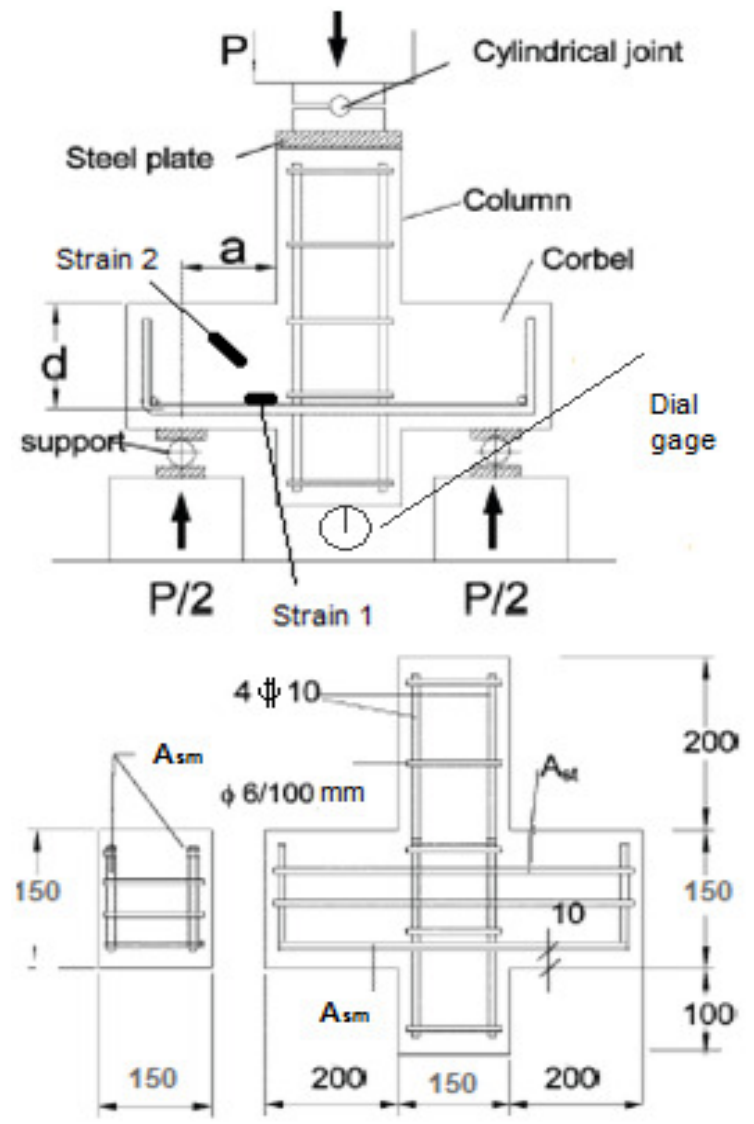

Fig 1-Load scheme of corbels and specimens geometry (mm) 
Table 1. Details of Specimens

\begin{tabular}{|c|c|c|c|c|c|c|}
\hline 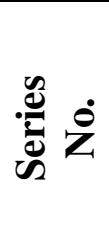 & 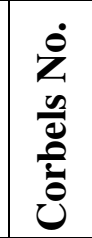 & $\underbrace{2} \frac{E}{\xi}$ & $\Delta^{\circ}$ & $\S$ & 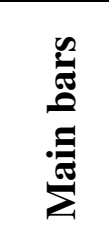 & 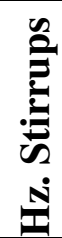 \\
\hline \multirow{3}{*}{$\underline{\boldsymbol{A}}$} & B1 & 70.5 & 0 & 0.6 & $2 \Phi 16$ & --- \\
\hline & B3 & 82 & 1.0 & 0.6 & $2 \Phi 16$ & --- \\
\hline & B4 & 75 & 1.5 & 0.6 & $2 \Phi 16$ & --- \\
\hline$\underline{B 1}$ & B5 & 82.4 & 0 & 0.45 & $2 \Phi 16$ & --- \\
\hline \multirow{2}{*}{3} & B7 & 82.4 & 0 & 0.75 & $2 \Phi 16$ & --- \\
\hline & B6 & 96.4 & 1.0 & 0.45 & $2 \Phi 16$ & --- \\
\hline$\underline{B 2}$ & B8 & 96.4 & 1.0 & 0.75 & $2 \Phi 16$ & --- \\
\hline \multirow{4}{*}{$\underline{c}$} & B9 & 62.7 & 0 & 0.6 & $2 \Phi 16$ & --- \\
\hline & B11 & 106.5 & 0 & $\begin{array}{ll}0.6 \\
\end{array}$ & $2 \Phi 16$ & -- \\
\hline & B10 & 65 & 1.0 & 0.6 & $2 \Phi 16$ & --- \\
\hline & B12 & 106 & 1.0 & 0.6 & $2 \Phi 16$ & --- \\
\hline & B17 & 73 & 0 & 0.6 & $2 \Phi 12$ & --- \\
\hline & B19 & 73 & 0 & 0.6 & $2 \Phi 18$ & --- \\
\hline & B18 & 94 & 1.0 & 0.6 & $2 \Phi 12$ & -- \\
\hline & B20 & 73 & 1.0 & 0.6 & $2 \Phi 18$ & --- \\
\hline \multirow{2}{*}{$\underline{\underline{E} \underline{\underline{E 2}}}$} & B15 & 85 & 0 & 0.6 & $2 \Phi 16$ & $2 \phi 6$ \\
\hline & B16 & 78.3 & 1.0 & 0.6 & $2 \Phi 16$ & $2 \phi 6$ \\
\hline
\end{tabular}

\subsection{Materials}

- Concrete mix design was made to produce high strength concrete have cubic compressive strength of 60,80 and $100 \mathrm{~N} / \mathrm{mm}^{2}$ after 28 days. Concrete mix proportions are given in Table 2 .

- Ordinary Portland cement and local natural sand were used. The coarse aggregate was crushed basalt with a maximum nominal size of $10 \mathrm{~mm}$ and 20 $\mathrm{mm}$.

- To enhance the strength of the concrete by means of pore -refinement, Silica Fume was used. A high-range water-reducing admixture under a commercial name of Sekament F.F.3 was used to improve the workability of the mix.

- Deformed bars of about $400 \mathrm{~N} / \mathrm{mm}^{2}$ proof strength and having diameter 10, 12, 16 and $18 \mathrm{~mm}$ were used as main bars and column compression bars. The stirrups used were made of $6 \mathrm{~mm}$ diameter smooth bars of $330 \mathrm{~N} / \mathrm{mm}^{2}$ yield strength.

- Only one type of steel fibers -under a commercial name HAREX, made of steel having a minimum tensile strength of $400 \mathrm{~N} / \mathrm{mm}^{2}$ was used. The fibers were of $24 \times 1.9 \times 0.4 \mathrm{~mm}$ dimensions, with hooked-ends, and aspect ratio equals 24 .

- All used materials are agreed with ECC. 
Table 2. Concrete mix proportions

\begin{tabular}{|c|c|c|c|c|c|c|c|}
\hline \multirow[b]{2}{*}{$\begin{array}{l}\text { Concrete } \\
\text { Strength } \\
\mathrm{N} / \mathrm{mm}^{2}\end{array}$} & \multirow[b]{2}{*}{$\begin{array}{c}\text { Cement } \\
\mathrm{Kg} / \mathrm{m}^{3}\end{array}$} & \multirow{2}{*}{$\begin{array}{c}\text { Fine } \\
\text { Aggre } \\
\text { gate } \\
\mathrm{Kg} / \mathrm{m}^{3}\end{array}$} & \multicolumn{2}{|c|}{ Coarse Aggregate } & \multirow{2}{*}{$\begin{array}{l}\text { Silica } \\
\text { Fume } \\
\underset{3}{\mathrm{Kg} / \mathrm{m}}\end{array}$} & \multirow[b]{2}{*}{$\begin{array}{c}\text { Super- } \\
\text { Plasticizer } \\
\text { Liter } \\
/ \mathbf{m}^{\mathbf{3}}\end{array}$} & \multirow[b]{2}{*}{$\begin{array}{c}\text { Water } \\
\text { Liter } \\
/ \mathbf{m}^{3}\end{array}$} \\
\hline & & & $\begin{array}{l}\text { M.N.S } \\
10 \text { mm } \\
\text { Kg/m } \mathbf{m}^{3}\end{array}$ & $\begin{array}{l}\text { M.N.S } \\
20 \mathrm{~mm} \\
\mathrm{Kg} / \mathrm{m}^{3}\end{array}$ & & & \\
\hline 60 & & 600 & 600 & $\overline{6000}$ & 70 & $\overline{14}$ & $\overline{165}$ \\
\hline 80 & 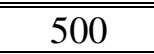 & $\overline{525}$ & 800 & 6000 & 90 & $\begin{array}{ll} \\
\end{array}$ & $\overline{11}$ \\
\hline 100 & 550 & 450 & 600 & 600 & 110 & 20 & 138 \\
\hline
\end{tabular}

\subsection{Test Setup and Measurements}

A hydraulic testing machine with bearing capacity of $600 \mathrm{kN}$ was used. The load scheme adopted is shown in Fig 1. Corbels tested were supported symmetrically by two steel hinges placed at a distance (a) from the face of column as shown in Fig. 1. At each load incensement, vertical deflection of center of bottom surface of column, steel strain of main bar and concrete strain were recorded. Also for all corbels, the cracking load and the ultimate load are recorded while the patterns of crack propagation were observed.

\section{TEST RESULTS}

\subsection{Pattern of Cracks and Mode of Failure}

The first crack to appear was flexural crack starting at or near the column corbel interface and subsequent flexural cracks away from this section were formed. As this applied load increased, one of the flexural cracks in the shear span extended diagonally upward toward the corbel-column connection, or a diagonal crack formed at the mid height of the corbel within the shear span. After the formation of the diagonal cracks, corbels with higher volume of fibers or/and horizontal stirrups showed higher load carrying capacity. All corbels failed in shear and the failure was as follows. Finally all corbels failed by the extension of the diagonal crack toward the corbel-column connection. As shown in Fig 2. The trend of cracking was almost the same, except that the number of the cracks seemed to depend on the fiber or/and horizontal stirrups content. Corbels without fibers or without horizontal stirrups, exhibited a sudden failure. It has to be mentioned that the presence of high percentage of either steel fibers or/and horizontal stirrups transformed the failure mode into a more ductile one and increased the number of the diagonal cracks formed (Fig 2-a, Fig. 2-e). This indicates that steel fibers or/and horizontal stirrups became effective after shear cracks formed and continued to resist the principal tensile stress until failure occurred at one critical crack. However, increase in shear span-to- depth ratio transformed the failure mode to more ductile one and increased the number of the formed cracks (Fig 2-b). Also, increase in concrete compressive strength or percentage of main steel reinforcement results in increasing the first crack load, transforming the mode of failure into more brittle behaviour and reduces the number of the cracks (Fig 2-c, Fig 2-d). 


\subsection{Load Deflection Curves:}

The load-deflection relationships for all tested corbels are shown in (Fig 3 to Fig 7). From these figures the following observations can be conclude:

- When fibers are present, an increase in strength capacity, about $19 \%$ in failure load of corbel was observed and at the same time the ductility improved by about $20 \%$. It has to be mentioned that an increase of $30 \%$ in failure load was recorded by G. Campione et.al. [1] in case of flexural behavior.

- Increasing the shear span-to-depth ratio (a/d) decreasing the failure load and increasing the deflection of corbels with and without fibers (Fig 4).

- As expected, increasing concrete strength leads to increase carrying capacity of the corbels. Also, it is noticed that the ductility of FRC corbels increased in comparison with those without fibers. This confirms the advantage of using fiber in increasing ductility of corbels (Fig 5).

- Increase the main steel ratio results in increasing corbel strength. Effect of addition of fibers to improve behaviour of specimen was clear in case of corbels having smaller main steel ratio (Fig 6).

- Using horizontal stirrups, gives a little increase in corbels strength and decreases deflection of corbels. Moreover, the addition of fibers allows the attainment of complete flexural capacity and, consequently, a more ductile response (Fig 7).

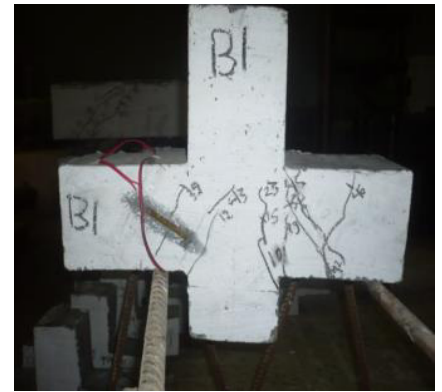

without fibers

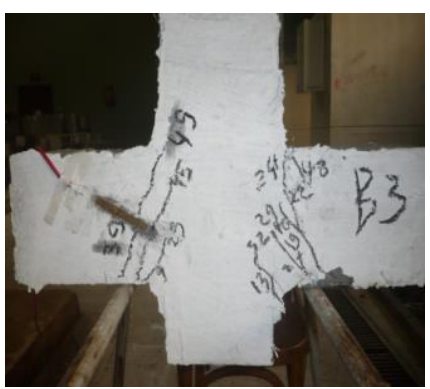

with $1.0 \%$ fibers

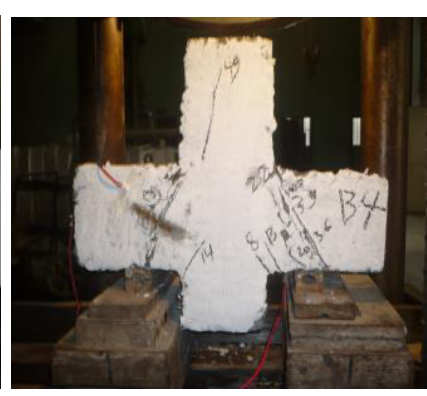

with $1.5 \%$ fibers

(a) Effect of fiber content

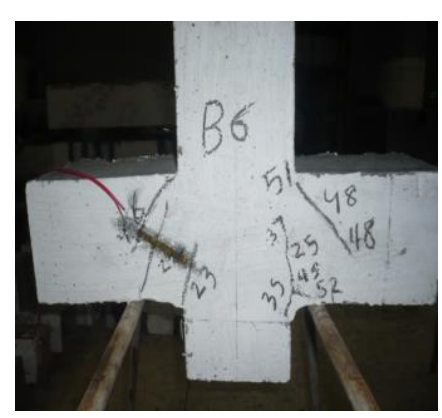

$\mathrm{a} / \mathrm{d}=0.45$

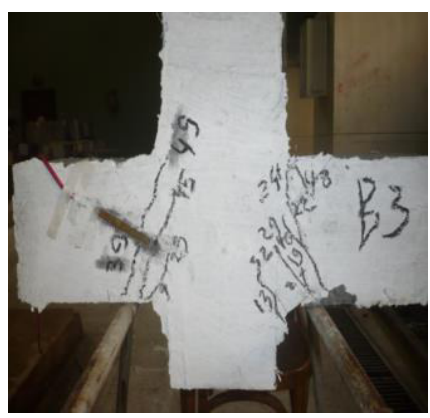

$\mathrm{a} / \mathrm{d}=0.6$

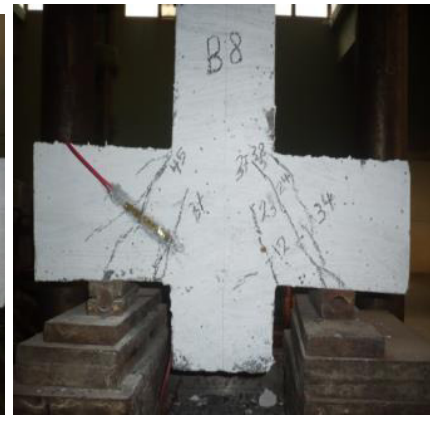

$\mathrm{a} / \mathrm{d}=0.75$

(b) Effect of shear span-to-depth ratio 


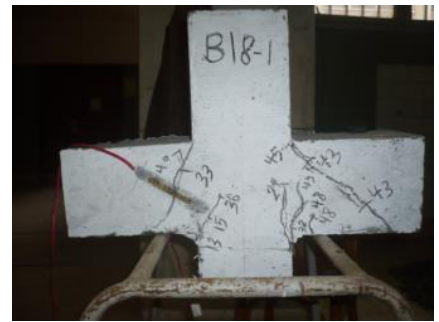

$2 \Phi 12$ main reinforcement $2 \Phi 16$ main reinforcement $2 \Phi 18$ main reinforcement

(c) Effect of main reinforcement

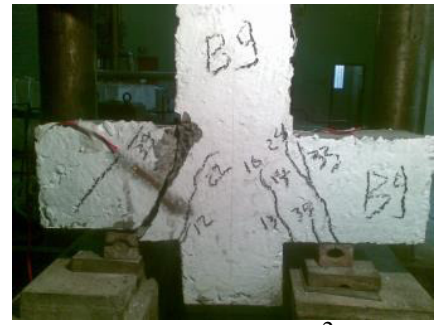

$f_{c u}=62.7 \mathrm{~N} / \mathrm{mm}^{2}$
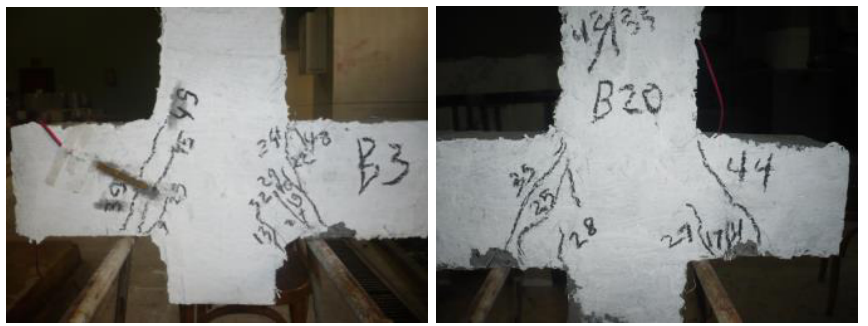

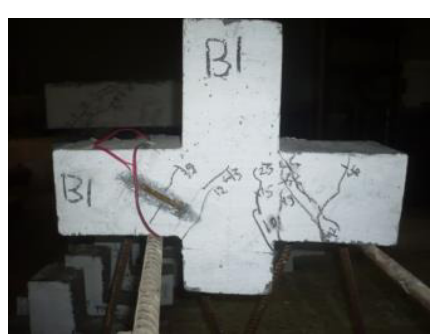

$f_{c u}=70.5 \mathrm{~N} / \mathrm{mm}^{2}$

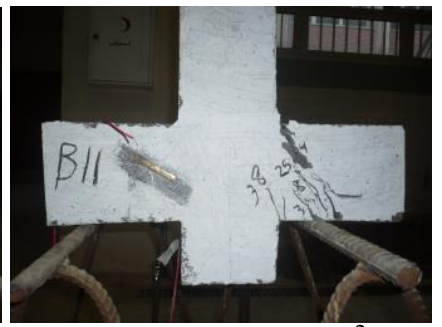

$f_{c u}=106.5 \mathrm{~N} / \mathrm{mm}^{2}$

(d) Effect of concrete strength

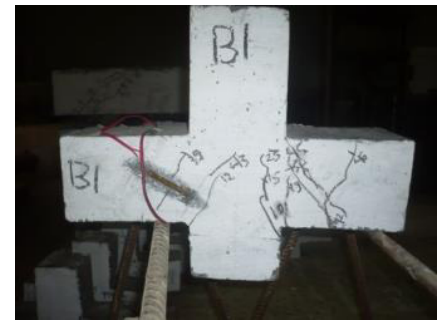

without horizontal stirrups

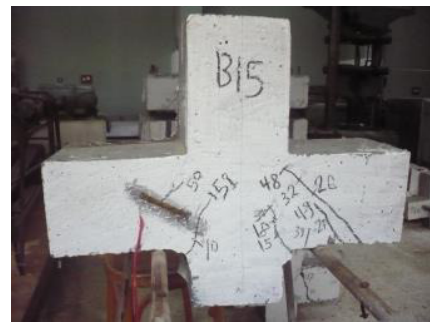

$2 \phi 6$ horizontal stirrups

(e) Effect of horizontal stirrups

Fig 2-Effect of studied variable on cracks pattern

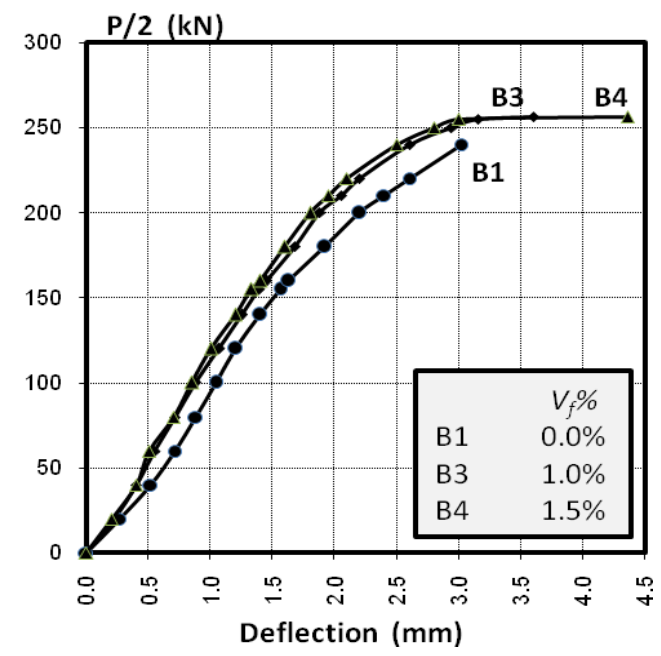

Fig 3-Effect of fiber content on load-deflection curve 

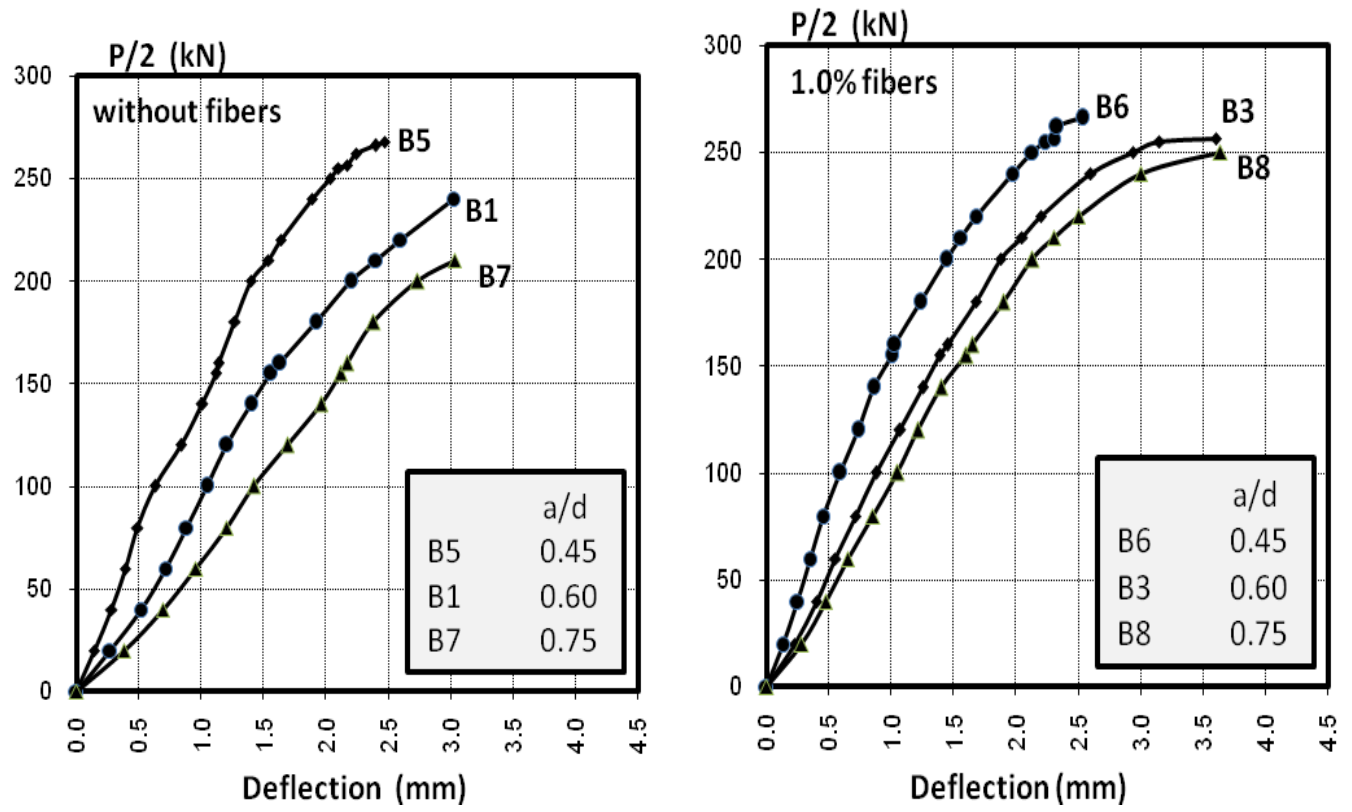

Fig 4-Effect of shear span-to-depth ratio on load-deflection curve
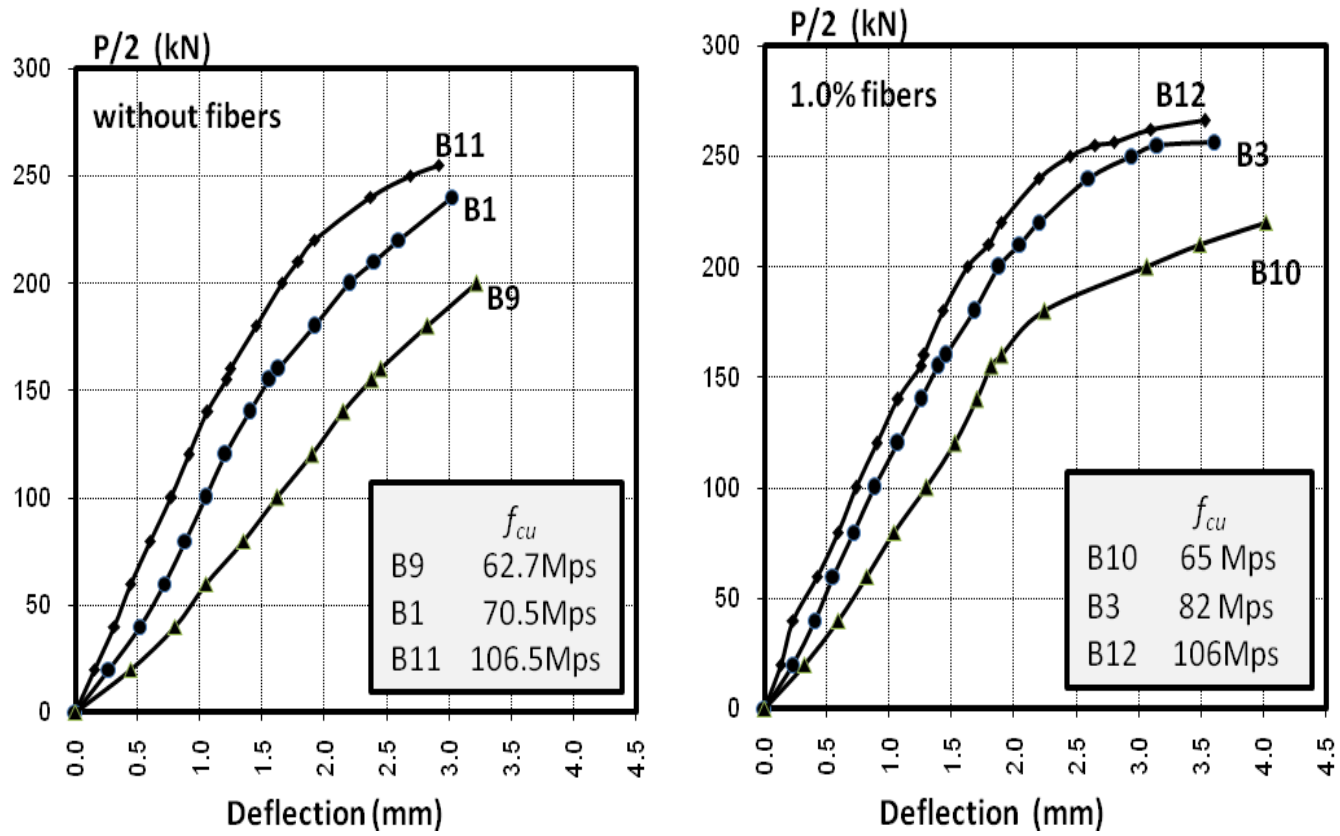

Fig 5-Effect of concrete strength on load- deflection curve 

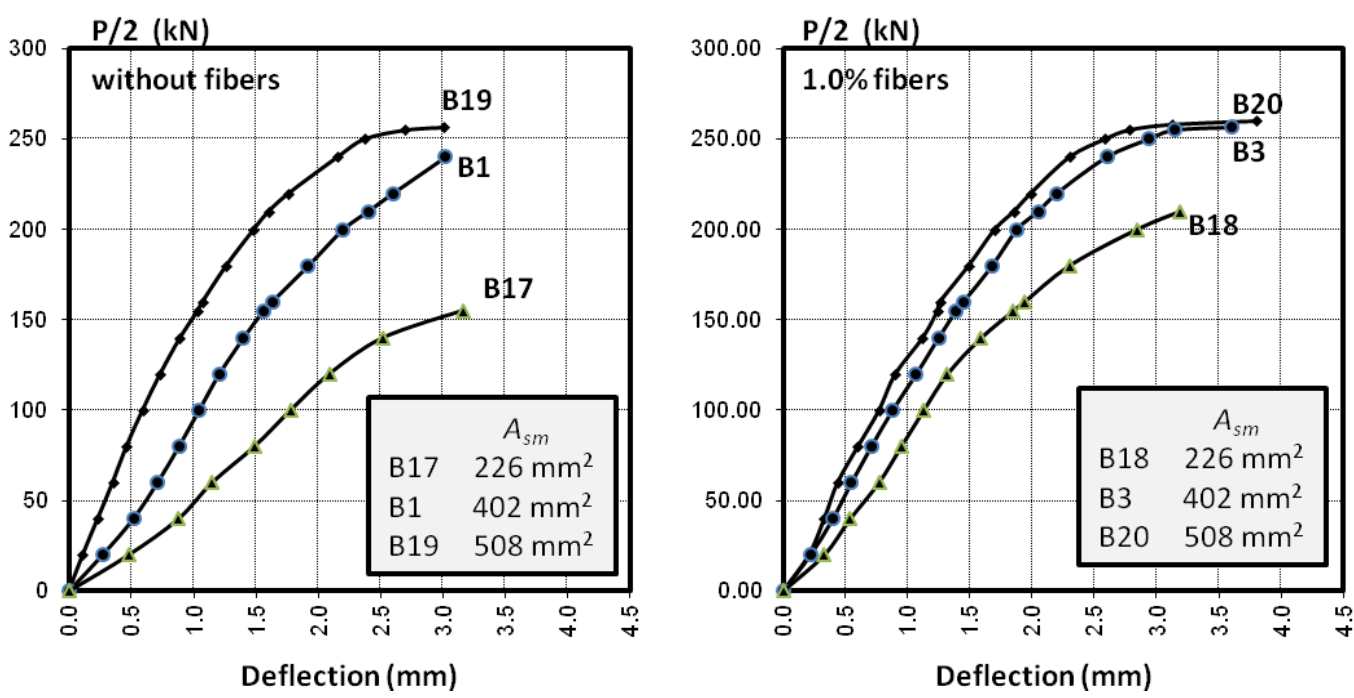

Fig 6-Effect of area of main reinforcement on load-deflection curve
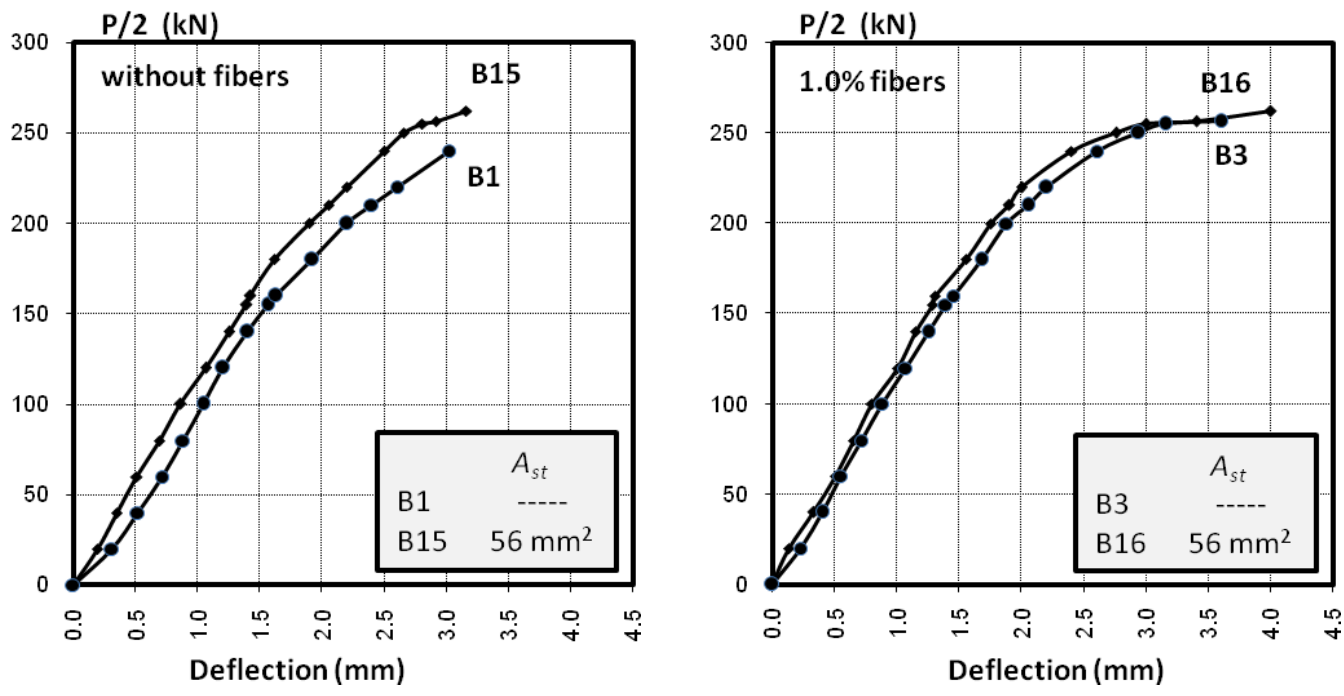

Fig 7-Effect of horizontal stirrups on load-deflection curve

\subsection{Longitudinal Bar Strains}

The variation of strain measured in tension reinforcement with increase in load is shown in Fig 8 to Fig 11 for some chosen corbels. These figures showed that, increasing either fiber content $\left(V_{f} \%\right)$, area of main steel $\left(A_{s m}\right)$ or presence of horizontal stirrups decreased the strain of main steel for the same load. Also increase of shear span-to-depth ratio (a/d) leads to increase in the strain in main steel (Fig 9). However, all reinforced concrete corbels provided with steel fibers showed a small decrease in the main steel strain at the same load compare with that of corbels without fiber. 


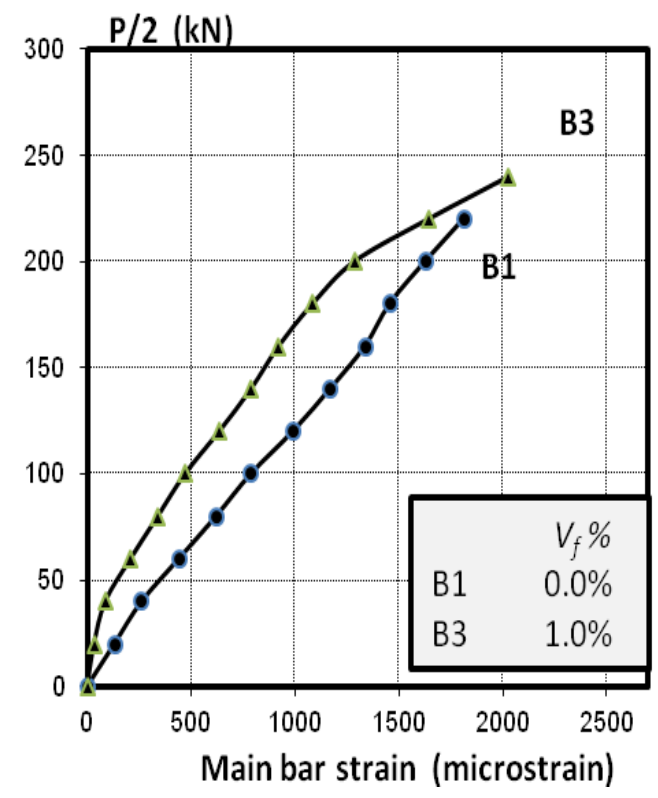

Fig 8-Influence of fiber content on main steel strain
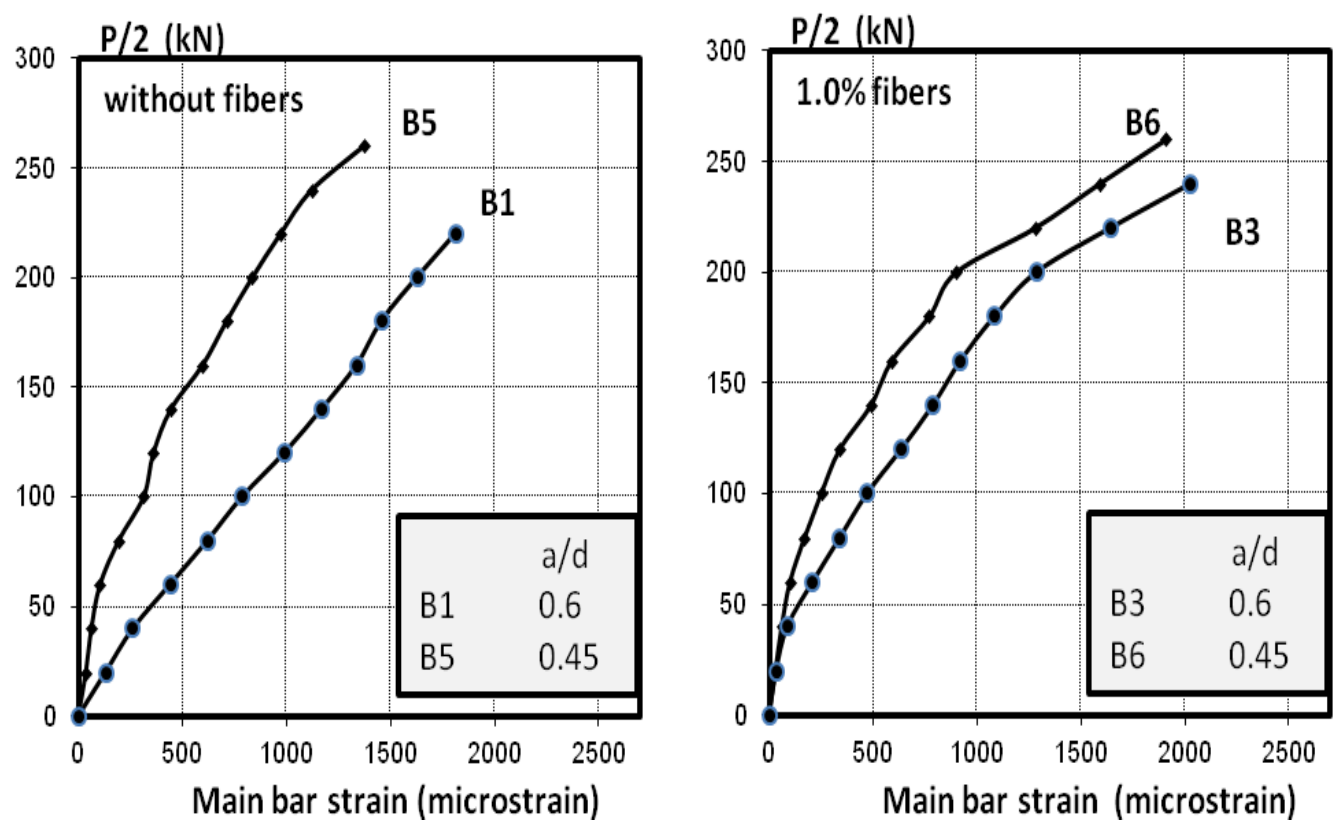

Fig 9-Influence of shear span-to-depth ratio on main steel strain 

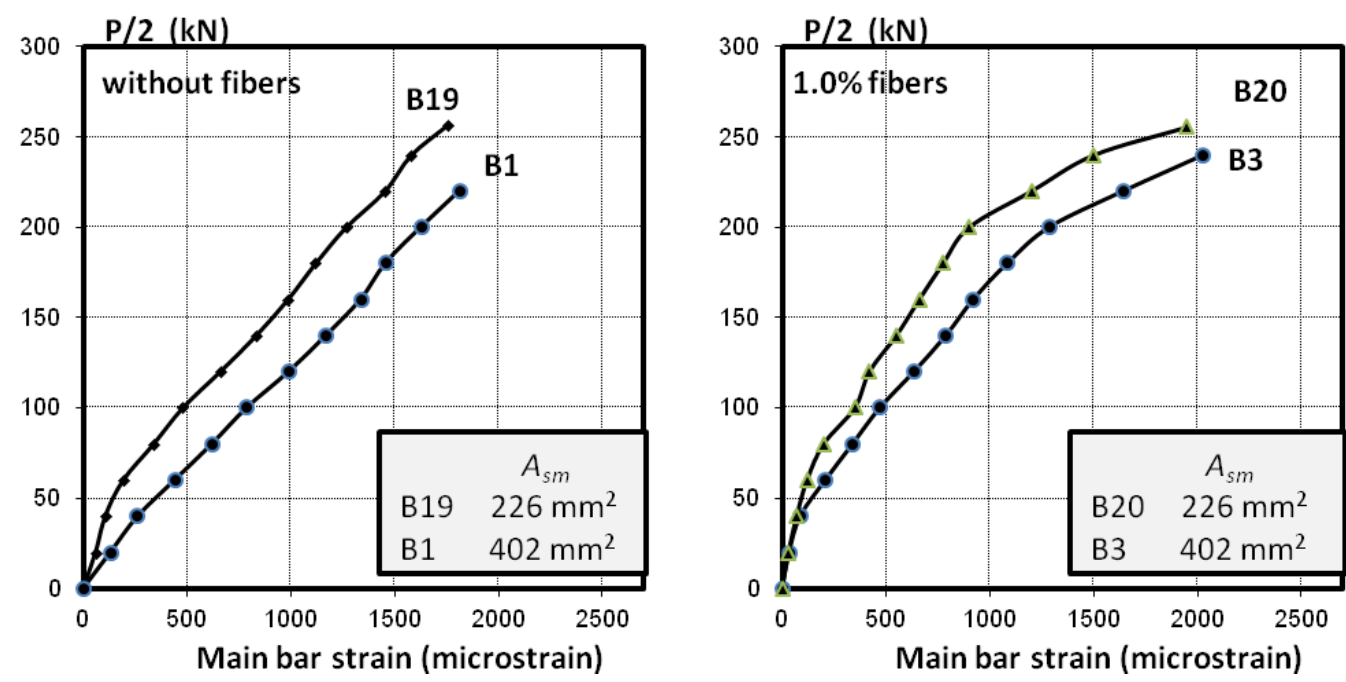

Fig 10-Influence of area of main steel reinforcement on main steel strain
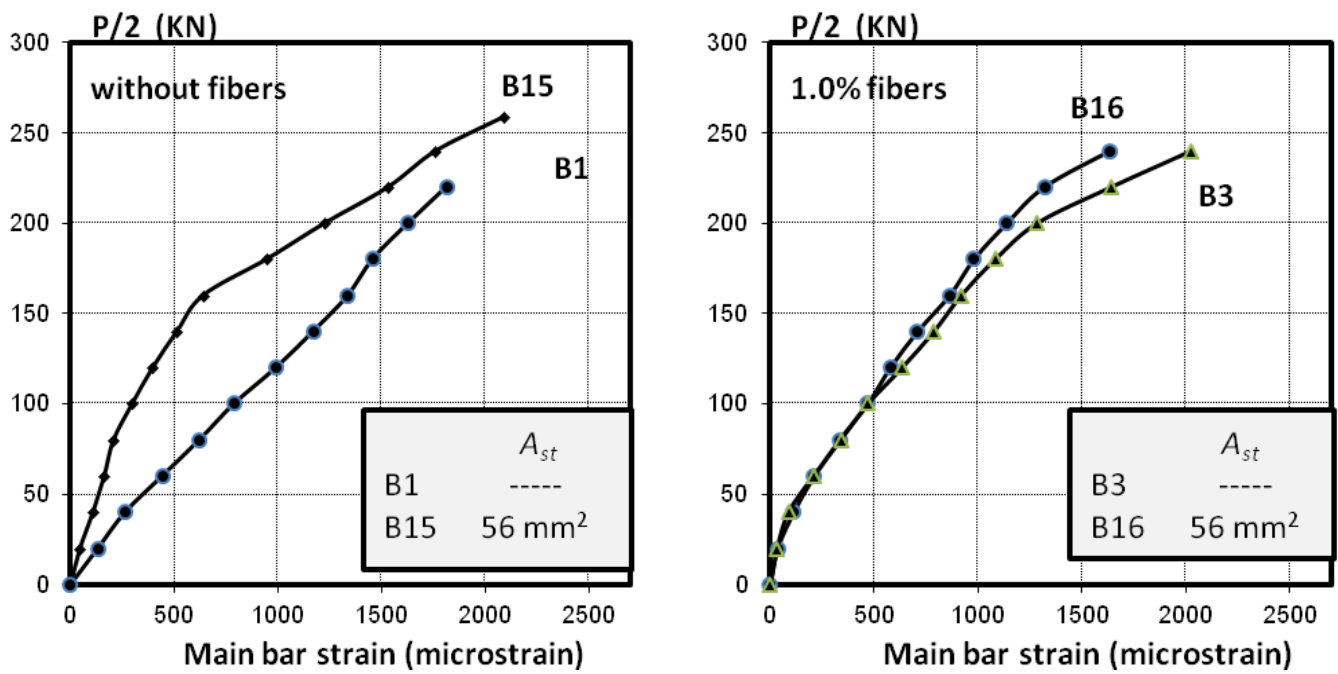

Fig 11-Influence of presence of horizontal stirrups on main steel strain

\section{DISCUSSION OF TEST RESULTS}

\subsection{Effect of Studied Variables on ultimate load and deflection at 90\% ultimate load:}

The obtained test results were analyzed to declare the effect of the various parameters included in this work on strength and deformation up to failure. These properties were measured by means of ultimate load and maximum deflection at $90 \%$ ultimate load, as follows:

\subsubsection{Effect of Steel Fiber Content:}

Figure 12 shows that increase in fiber contents from $0 \%$ to $1.0 \%$ and $1.5 \%$ results in an increase in ultimate capacity by $19 \%$ in failure load of corbel. However, this increase 
leads to increase from $20 \%$ to $45 \%$ respectively in deflection at $0.9 \mathrm{P}_{\mathrm{u}}$ of corbels. It has to be mentioned that an increase of $7.3 \%$ in failure load was recorded by N. Fattuhi et.al. [13] in case of corbels made of normal strength concrete. This behavior confirms the effect of fiber in improving ductility of high strength concrete.
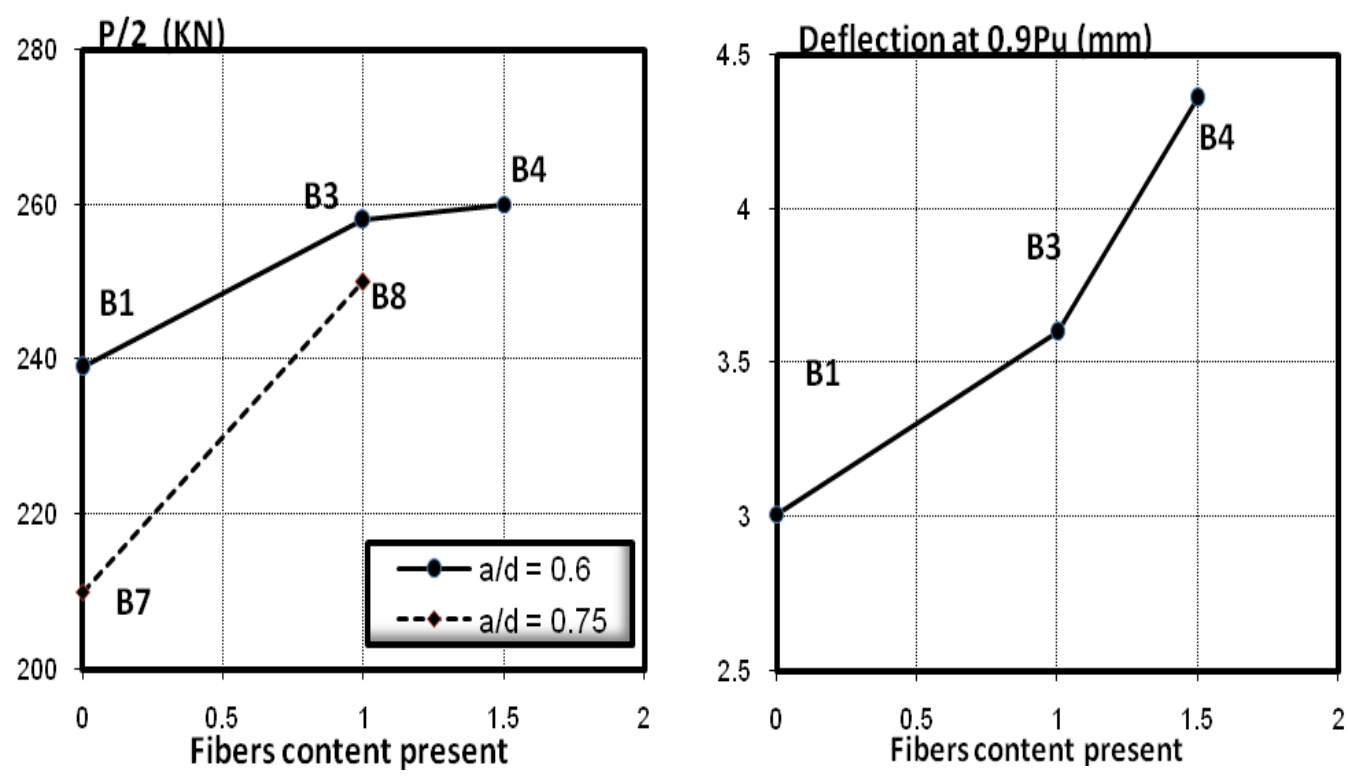

Fig 12-Effect of fiber content on failure load and deflection at $0.9 \mathrm{P}_{\mathrm{u}}$

\subsubsection{Effect of Shear Span-to-Depth Ratio:}

Figure 13 shows that increase in shear span-to-depth ratio from 0.45 to 0.6 and 0.75 results in a decrease of $10.4 \%$ and $21.6 \%$ respectively in failure load of corbels without fibers and a decrease of $3 \%$ and $6 \%$ respectively in failure load of corbels with $1.0 \%$ fibers content. However, this increase leads to increase of $22 \%$ and $23 \%$ respectively in deflection at $0.9 \mathrm{P}_{\mathrm{u}}$ of corbels without fibers and increase of $42.3 \%$ and $44 \%$ respectively in deflection at $0.9 \mathrm{P}_{\mathrm{u}}$ of corbels with $1.0 \%$ fibers content. It has to be mentioned that a decrease of $33 \%$ in failure load of normal strength concrete corbels without fibers and a decrease of $20 \%$ in failure load of normal strength concrete corbels with $1.0 \%$ fibers were recorded by N. Fattuhi et.al. [13] in case of increase in shear span-to-depth ratio from 0.59 to 0.83 . It can be noticed also that improvement in ultimate load and ductility due to the presence of fibers content was more significant at higher span-to-depth ratio. 

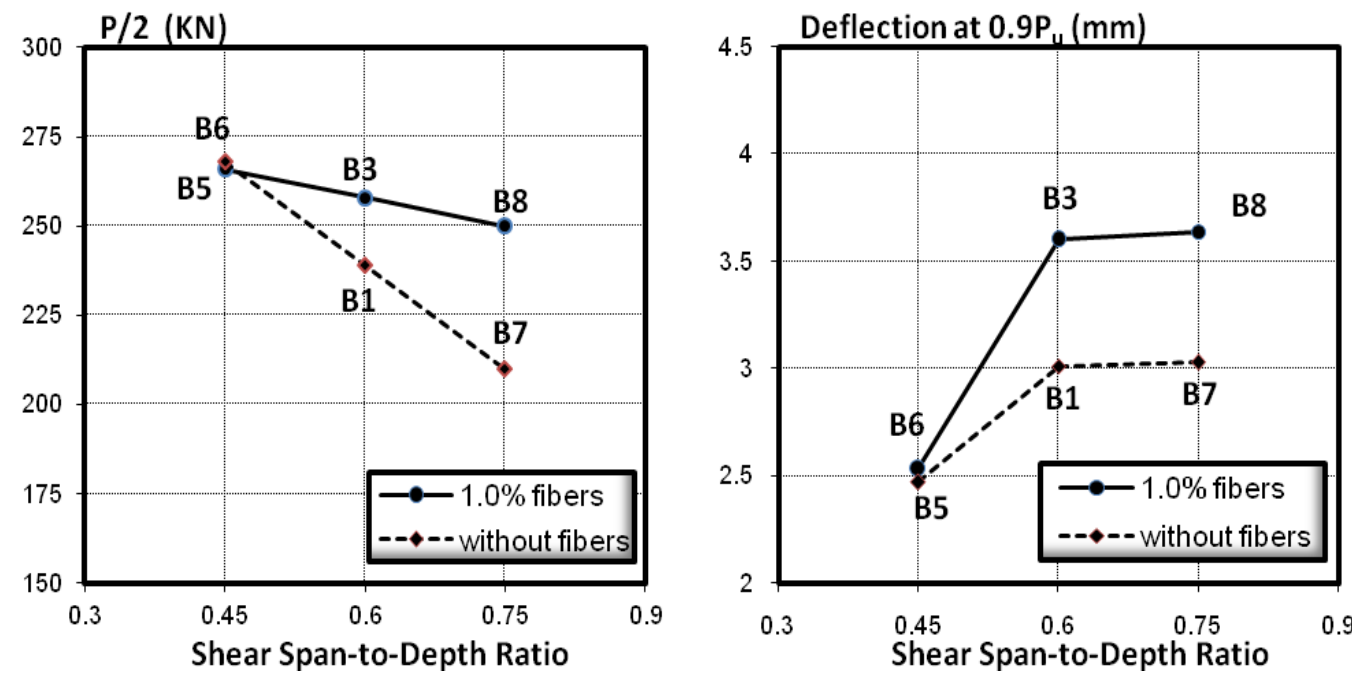

Fig 13-Effect of Shear Span-to-depth Ratio on failure load and deflection at $0.9 \mathrm{P}_{\mathrm{u}}$

\subsubsection{Effect of Concrete Strength:}

Figure 14 shows that increase in concrete strength from $62.7 \mathrm{~N} / \mathrm{mm}^{2}$ to $70.5 \mathrm{~N} / \mathrm{mm}^{2}$ and $106.5 \mathrm{~N} / \mathrm{mm}^{2}$ results in an increase of $17.7 \%$ and $25.6 \%$ respectively in failure load and a decrease of $6.8 \%$ and $9.6 \%$ respectively in deflection at $0.9 \mathrm{P}_{\mathrm{u}}$ of corbels without fibers. Moreover, increase in concrete strength from $65 \mathrm{~N} / \mathrm{mm}^{2}$ to $82 \mathrm{~N} / \mathrm{mm}^{2}$ and 106 $\mathrm{N} / \mathrm{mm}^{2}$ results in an increase of $17.3 \%$ and $19.1 \%$ respectively in failure load and a decrease of $10.4 \%$ and $12.2 \%$ respectively in deflection at $0.9 \mathrm{P}_{\mathrm{u}}$ of corbels with $1.0 \%$ fibers content. It has to be mentioned that an increase of $14.3 \%$ in failure load of corbels without fibers was recorded by Y. Yong et.al. [4] in case of increase in concrete strength from $39 \mathrm{~N} / \mathrm{mm}^{2}$ to $54.7 \mathrm{~N} / \mathrm{mm}^{2}$. It can be noticed also that the improvement in ultimate load and ductility due to the presence of fibers content was more significant in those with higher concrete strengthes.
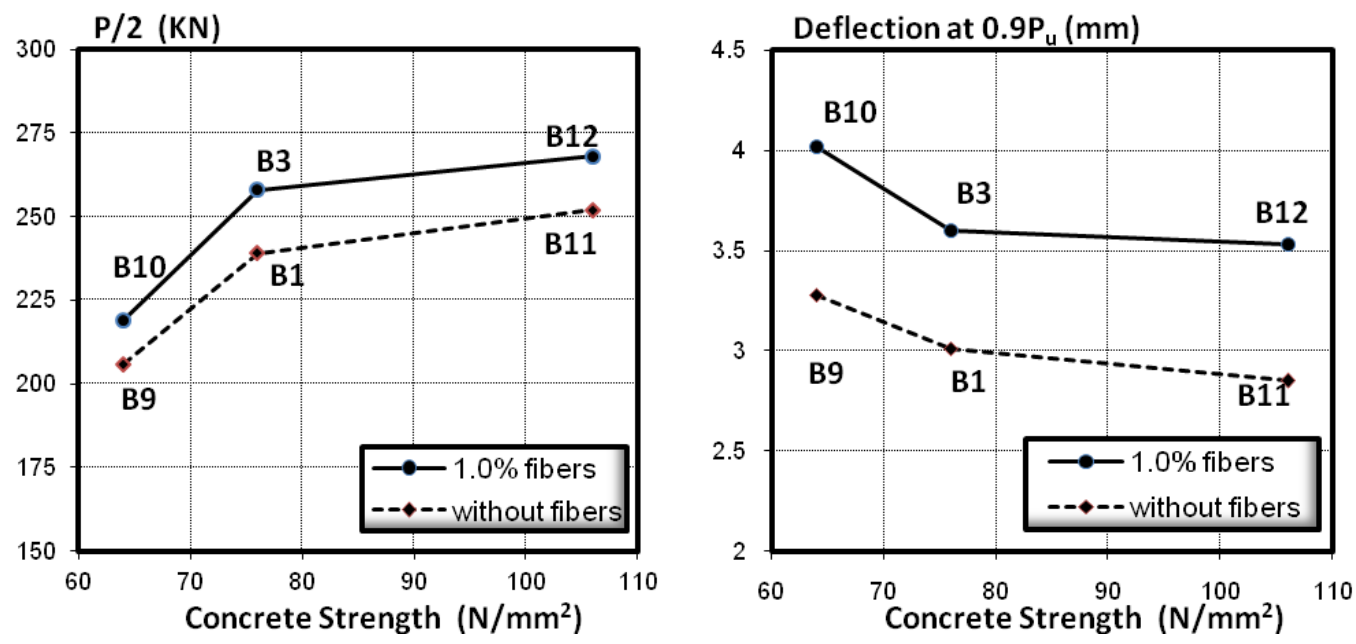

Fig 14-Effect of Concrete strength on failure load and deflection at $0.9 \mathrm{P}_{\mathrm{u}}$ 


\subsubsection{Effect of Main Reinforcement:}

It is clear from Fig. 15, that increase in main steel reinforcement ratio from $1.16 \%$ to $2.06 \%$ and $2.61 \%$ results in an increase of $54.2 \%$ and $65.2 \%$ respectively in failure load of corbels without fibers and an increase of $22.3 \%$ in failure load of corbels with $1.0 \%$ fibers content. However, this increase leads to decrease of $4.7 \%$ in deflection at $0.9 \mathrm{P}_{\mathrm{u}}$ of corbels without fibers and increase of $12.9 \%$ and $19.1 \%$ respectively in deflection at $0.9 \mathrm{P}_{\mathrm{u}}$ of corbels with $1.0 \%$ fibers content. It has to be mentioned that an increase of $89 \%$ in failure load of corbels without fibers and an increase of $67 \%$ in failure load of corbels with $1.0 \%$ fibers were recorded by N. Fattuhi et.al. [13] in case of increase in main steel reinforcement ratio from $0.51 \%$ to $1.16 \%$. It can be then noticed that improvement in ultimate load due to increase fibers content was more significant in lower main steel reinforcement ratios. The addition of fibers makes the effect of the multi-axial state of stress to develop yielding stress in steel bars and it results in higher ductility.
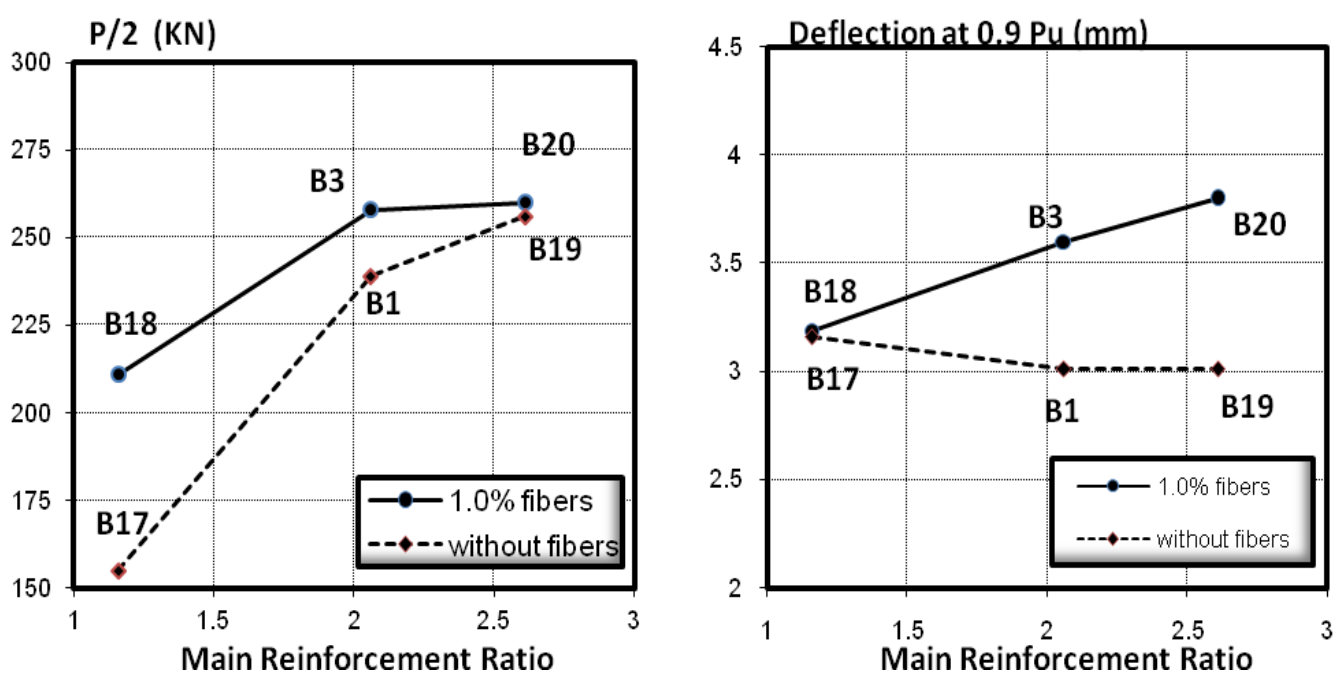

Fig 15-Effect of Main Reinforcement Ratio on failure load and deflection at $0.9 \mathrm{P}_{\mathrm{u}}$

\subsubsection{Effect of Horizontal Stirrups:}

It is clear from Fig. 16, that when horizontal steel reinforcement is presented, both the ultimate load and maximum deflection have been increased by $8.4 \%$ in failure load and $5 \%$ in deflection at $0.9 \mathrm{P}_{\mathrm{u}}$ of corbels without fibers. However, for an increase of $0.8 \%$ in failure load and $11.1 \%$ in deflection at $0.9 \mathrm{P}_{\mathrm{u}}$ were recorded of corbels with $1.0 \%$ fibers. It has to be mentioned that an increase of $58 \%$ in failure load of corbels without fibers and an increase of $19 \%$ in failure load of corbels with $1.0 \%$ fibers were recorded by G. Campione et.al. [1] in case of flexural behavior. It can be also noticed that improvement in ultimate capacity due to increase in fibers content was more significant in case of corbels without horizontal stirrups. 

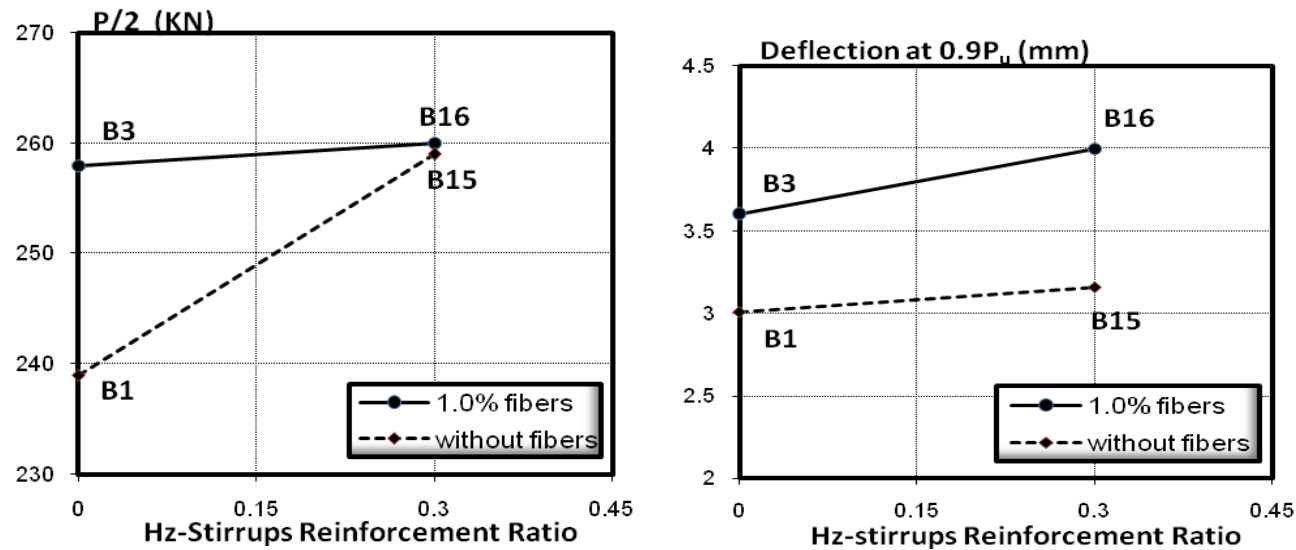

Fig 16-Effect of Hz-Stirrups Reinforcement Ratio on failure load and deflection at $0.9 \mathrm{P}_{\mathrm{u}}$

\subsection{Comparison between Experimental and Predicted Ultimate \\ Loads:}

Many equations have been proposed to estimate the ultimate strength of reinforced concrete corbels. Among them, the ACI code [13], Fattuhi equation [10], Truss method [14] and G. Compione propose [1].

These equations can briefly presented as follows:

\section{a) ACI code equation [14]}

The ACI current design produces for corbels were based on shear friction and empirical relationship based on the flexural capacity of the section. The smallest of the three values is used for design. The three basic equations allowed for design of the corbels by ACI-318 are given as follows:

- Shear friction strength:

$$
V_{u}=\phi \mu A_{v} f_{y}
$$

$\mathrm{kN}$

-Flexural strength:

$$
\begin{aligned}
& V_{u}=\frac{M_{u}}{a} \\
& M_{u}=\phi \mu A_{s m} f_{y}\left(d-\frac{A_{s m} f_{y}}{1.7 f_{c}^{\prime} b}\right) \\
& \mathrm{kN} . \mathrm{m}
\end{aligned}
$$

- Maximum shear strength

$$
V_{u}=0.2 f_{c}{ }^{\prime} b d \quad \mathrm{kN}
$$

Where: $V_{u}=$ corbel strength $(\mathrm{N}), \varnothing=$ strength reduction factor (assumed to be 1.0), $\mu$ =coefficient of friction (assumed to be 1.4 for monolithic concrete), $A_{v}=$ area of reinforcement extending across the critical section $\left(\mathrm{mm}^{2}\right)$, $f_{y}=$ yield strength of the main reinforcement $\left(\mathrm{N} / \mathrm{mm}^{2}\right), M_{u}=$ flexural moment (N.m), a = shear span length $(\mathrm{mm}), \mathrm{b}=$ width of corbels $(\mathrm{mm}), f_{c}{ }^{\prime}=$ cylinder compressive strength $\left(\mathrm{N} / \mathrm{mm}^{2}\right), \mathrm{d}=$ overall depth of corbel $(\mathrm{mm})$.

In using the above equations, cylinder compressive strength of concrete $f_{c}^{\prime}$ is required. For the reason that $f_{c}^{\prime}$ was not directly available from the tests, the following conversion formula proposed by Neville [15] was employed. 


$$
f_{c}^{\prime}=\left[0.76+0.2 \log _{10}\left(\frac{f_{c u}}{19.59}\right)\right] f_{c u}
$$

\section{b) Fattuhi equation [10]}

The predicted values are obtained by using the following modified shearfriction equation suggested by Fattuhi [10]

$$
V_{u}=\phi\left(\eta A_{v f} f_{f u} \mu\right)+\phi\left(A_{v} f_{y} \mu\right) \quad \mathrm{N}
$$

Where: $\eta=$ overall fiber efficiency factor $=0.1, A_{v f}=$ total area of fiber at critical section $\left(\mathrm{mm}^{2}\right), f_{f u}=$ ultimate tensile strength of the fiber $\left(\mathrm{N} / \mathrm{mm}^{2}\right)$, $\phi=$ strength reduction factor (assumed to be 1.0), $\mu=$ coefficient of friction (assumed to be 1.4 for monolithic concrete), $f_{y}=$ yield strength of the main reinforcement $\left(\mathrm{N} / \mathrm{mm}^{2}\right)$.

c) Truss analogy method [14]

The equations of the truss analogy method (Fig 17) proposed by Hagberg [14], can be listed as follows:

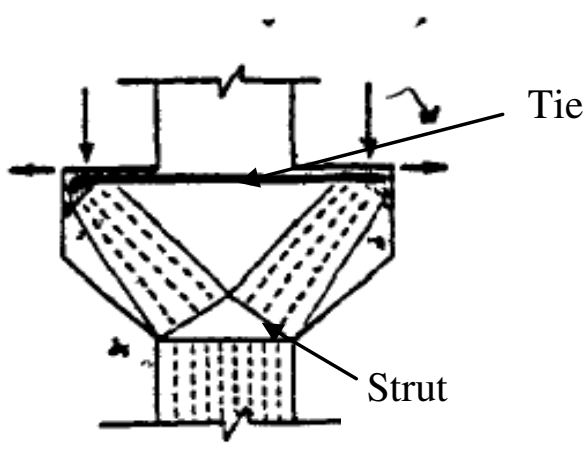

Fig 17-Truss analogy method [15]

$$
\begin{aligned}
F_{s}=A_{s m} & f_{y} \\
& V_{u}=\frac{F_{s}}{\tan \beta}
\end{aligned}
$$

Where: $F_{s}=$ force in main steel $(\mathrm{N}), f_{y}=$ yield strength of the main reinforcement $\left(\mathrm{N} / \mathrm{mm}^{2}\right), \beta=$ angle of inclination of the compressive concrete strut with vertical column

d) G. Campione proposes et.al. [1]

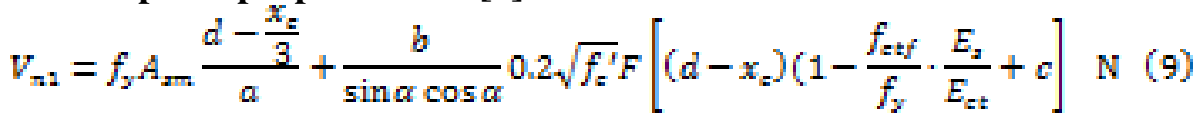

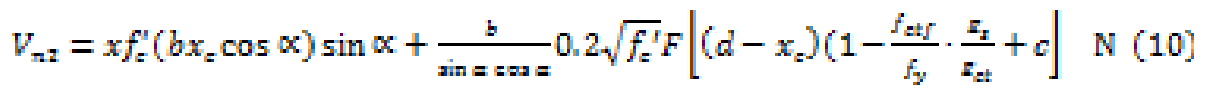

Where: $c=$ cover thickness $(\mathrm{mm}), E_{c t}=$ modulus of elasticity of fibers concrete $\left(\mathrm{N} / \mathrm{mm}^{2}\right), E_{s}=$ elastic modulus of steel $\left(\mathrm{N} / \mathrm{mm}^{2}\right), F=$ fiber factor, $f_{c}{ }^{\prime}=$ peak compressive strength of concrete $\left(\mathrm{N} / \mathrm{mm}^{2}\right), f_{c t f}=$ ultimate tensile strength of fibers concrete $\left(\mathrm{N} / \mathrm{mm}^{2}\right), f_{y}=$ yielding stress $\left(\mathrm{N} / \mathrm{mm}^{2}\right)$, $V_{n l}=$ ultimate shear force in case of steel failure in principal truss 
$\left(\mathrm{N} / \mathrm{mm}^{2}\right), V_{n 2}=$ ultimate shear force in case of compressive failure in principal truss $\left(\mathrm{N} / \mathrm{mm}^{2}\right), x_{c}=$ neutral axis depth $(\mathrm{mm}), \alpha=$ angle between strut and tie of principal truss, $\chi=$ a dimensional interpolating function (mm).

The smaller of the two values is used to predicate the ultimate load.

Table 3 and Fig. 18 show a compression between the experimental values of corbels capacity with those derived from the above equations. It can be noticed that G. Campione's equations [1] is estimated satisfactorily the ultimate load for high strength fiber reinforced concrete corbels.

Table 3. Corbels results and comparison between experimental and predicted ultimate load

\begin{tabular}{|c|c|c|c|c|c|c|c|c|c|c|c|c|c|c|}
\hline \multirow[b]{2}{*}{ 产 } & \multirow[b]{2}{*}{$\begin{array}{l}\frac{n}{8} \\
\frac{8}{8} \\
\frac{8}{3} \\
\end{array}$} & \multirow[b]{2}{*}{$\begin{array}{l}\mathbf{P}_{\mathrm{cr}} / 2 \\
(\mathrm{kN})\end{array}$} & \multicolumn{4}{|c|}{ mental Results } & \multicolumn{2}{|c|}{ 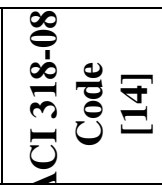 } & \multicolumn{2}{|c|}{ 氞 } & \multicolumn{2}{|c|}{ 党总 } & \multicolumn{2}{|c|}{ 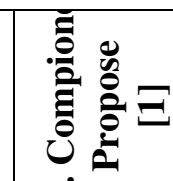 } \\
\hline & & & $\begin{array}{c}\delta_{\text {cr }} \\
(\mathrm{mm})\end{array}$ & & $\delta_{90}$ & 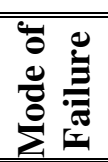 & 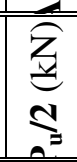 & 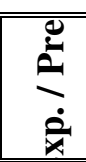 & 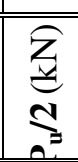 & 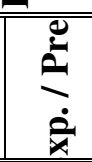 & 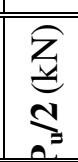 & 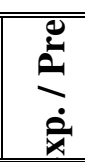 & 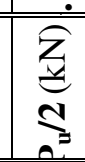 & ind \\
\hline & B1 & & & & & $S$. & 236 & 1.01 & 236 & 1.01 & 235 & 1.02 & 235 & 1.02 \\
\hline \multirow[t]{2}{*}{$\underline{\underline{A}}$} & 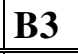 & & & & & & 236 & 1.09 & 264 & 0.98 & 40 & 1.07 & 254 & 1.01 \\
\hline & B & & & & & & 236 & 1.05 & 277 & \begin{tabular}{|l|}
0.89 \\
\end{tabular} & 237 & 1.05 & 257 & .97 \\
\hline & B5 & 45 & & & & & 236 & 1.13 & 236 & 1.13 & 300 & 0.89 & 300 & .89 \\
\hline & B7 & 4 & . & & & S. & 209 & 1.00 & 236 & 0.89 & 199 & 1.05 & 199 & 1.05 \\
\hline & B6 & 55 & 10 & & 2.5 & 5. & 236 & 1.13 & 264 & 1.01 & 308 & 0.86 & 326 & .82 \\
\hline & B8 & 55 & & & & & 212 & 1.18 & 264 & 0.95 & 202 & 1.24 & 217 & 15 \\
\hline & B9 & 45 & 0.1 & & 3.0 & S. & 236 & 0.86 & 236 & 0.86 & 231 & 0.88 & 231 & 0.88 \\
\hline & B11 & 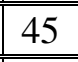 & 0.3 & & & S. & 236 & 1.08 & 236 & 1.08 & 248 & 1.03 & 248 & 1.03 \\
\hline & B10 & 55 & 1.1 & 220 & 4 & S. & 236 & 0.93 & 264 & 0.83 & 232 & 0.95 & 244 & 0.9 \\
\hline & B12 & & & & & & 236 & 1.11 & 264 & 0.99 & 248 & 1.06 & 265 & 0.99 \\
\hline & B17 & 45 & 0.5 & & 3.1 & S. & 133 & 1.17 & 133 & 1.17 & 142 & 1.09 & 142 & 1.09 \\
\hline \multirow{3}{*}{ F] } & B19 & 45 & 0.2 & 25 & 3. & S. & 299 & 0.86 & 299 & 0.86 & 288 & 0.89 & 288 & 0.89 \\
\hline & B18 & 55 & 1.3 & 21 & 3.1 & .S. & 133 & 1.59 & 160 & 1.32 & 146 & 1.45 & 162 & 1.3 \\
\hline & B20 & 55 & & & & & 299 & 0.86 & 327 & 0.79 & 288 & 0.90 & 300 & 0.86 \\
\hline & B15 & $5=$ & 0.0 & 25 & & S. & 262 & 0.99 & 263 & 0.98 & 251 & 1.03 & 251 & 1.03 \\
\hline & B16 & 60 & 1.24 & 26 & 4.0 & & 261 & 0.99 & 290 & 0.89 & 251 & 1.03 & & 0.97 \\
\hline & & & & & & & & & & 978 & & 28 & \\
\hline & & & & & & S.D. & & 172 & & 136 & & 146 & & 119 \\
\hline
\end{tabular}

Where:

$\begin{array}{llll}\text { Pcr. }= & \text { cracking load. } & \text { C.S. }= & \text { Catastrophic shear } \\ \text { Pu. }= & \text { ultimate load } & \text { D.S. }= & \begin{array}{l}\text { diagonal shear } \\ \text { flexural shear }\end{array} \\ \delta_{90}= & \text { deflection at cracking load. } & \text { F.S. }= & \text { deflection at } 0.9 \mathrm{Pu} \\ & & \end{array}$




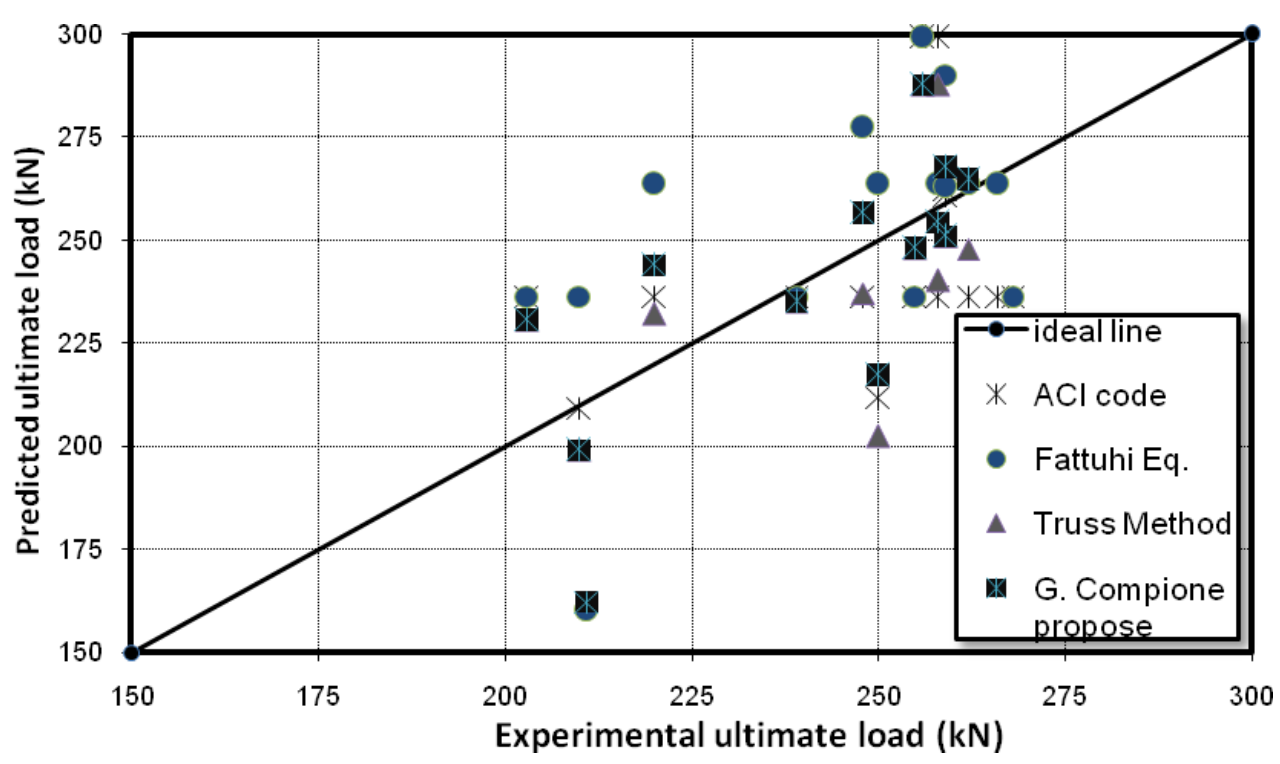

Fig 18-Comprasion between experimental and predicted ultimate loads

\section{CONCLUSIONS}

Based on the test results and the above discussions, the following conclusions can be drawn:

The presence of high percentage of fibers or/and horizontal stirrups transformed the mode of failure of the tested corbels into a more ductile one and increased the number of diagonal cracks.

Addition of steel fibers not only improves the shear strength of the tested corbels, but also increases the stiffness of these corbels. This improvement is more significant in case of corbels without stirrups.

The improvement in shear strength of tested corbels was more significant for corbels with low main reinforcement ratio or these with large shear span-to-depth ratio or those with lower concrete strength.

Increasing the main reinforcement results in an increase in the ultimate shear strength and leads to more ductile failure especially, when the fiber is presented.

Ultimate shear capacity of high strength fiber reinforced concrete corbels can be reasonably predicted by using Compione's equations.

\section{REFERENCES}

1. Giuseppe Campione, Lidia La Mendola, and Maria Letizia Mangiavillano, "Steel Fiber-Reinforced Concrete Corbels: Experimental Behavior and Shear Strength Prediction", ACI Structural Journal, V. 104, No. 5, Sep.-Oct. 2007.

2. Collins, M. P., and Michell, D., "Rational approach to shear design-the 1984 Canadian code provisions" ACI Struct. J., V. 83, No. 6, 1986.

3. Solanki, H., and Sabnis, G. M., "Reinforced concrete corbels-simplified" ACI Struct. J., V. 84, No. 5, 1987. 
4. Yong, Y., and Balaguru, P., "Behaviour of Reinforced High-Strength-Concrete Corbels" Journal of Structural Engineering, ASCE, V. 120, No. 4, 1994.

5. Foster, S. J., Powell, R. E., and Selim, H. S., "Performance of high-strength concrete corbels" ACI Struct. J., V. 93, No. 5, 1996.

6. Foster, S. J., and Malik, A. R., "Evaluation of efficiency factor models used in strut-and-tie modeling of nonflexural members" J. Struct. Eng., Vo. 128, No. 5, 2002.

7. Hwang, S., Lu, W., and Lee, H., "Shear strength prediction for reinforced concrete corbels" ACI Struct. J., V. 97, No. 4, 2000.

8. Hwang, S., and Lee, H., "Strength prediction for discontinuity regions by softened strut and tie model" J. Struct. Eng., V. 128, No. 12, 2002.

9. Russo, G., Venir, R., Pauletta, M., and Somma, G. "Reinforced concrete corbels shear strength model and design formula" ACI Struct. J., V. 103, No. 1, 2006.

10. Fattuhi Nijad I., "SFRC Corbels Tests," ACI Structural Journal, V. 84, No. 2, Mar.-Apr. 1987.

11. Hashim M. S. Abdul-Wahab, "Strength of Reinforced Concrete Corbels with Fibers," ACI Structural Journal,V. 86, Nov.-Dec. 1989.

12. Giuseppe Campione, "Performance of Steel Fibrous Reinforced Concrete Corbels Subjected to Vertical and Horizontal Loads," Journal of Structural Engineering, V. 135, No. 5, May. 2009.

13. Fattuhi Nijad, "Reinforced Steel Fiber Concrete Corbels with Various Shear Spanto-Depth Ratios", ACI Materials Journal V. 86, No. 6, Nov-Dec 1989.

14. ACI committee 318. "Building Code Requirement for Reinforcement Concrete (ACI 318-08)," American Concrete Institute, Detroit, 2008.

15. Hagberg, Thore, "Design of Concrete Brackets; On the Application of the Truss Analogy", ACI Journal, Proceedings V. 80, No. 1, January 1983

16. Nevielle, J. Taub, "Resistance to shear Reinforced Concrete Beams", ACI Structural Journal, V. 57, No. 6, November 1960. 


\section{سلوك القص فى الكوابيل الخرسانية المصنوعة من خرسانة عالية المقاومة تحتوى على ألياف من الصلب}

اجريت الدراسة المعملية فى هذا البحث بغرض دراسة سلوك القص فى الكوابيل الخرسانية المسلحة المصنوعة

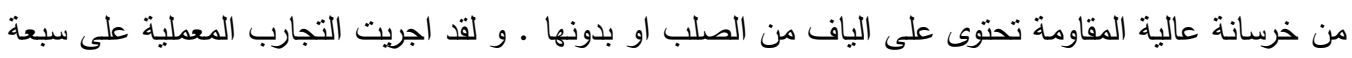

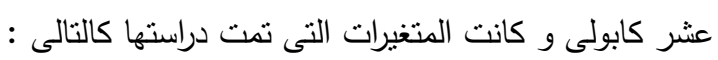

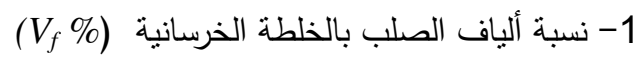

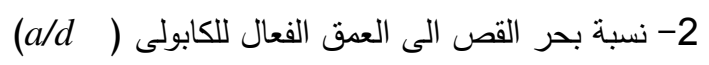

3- مقاومة الضغط للخرسانة

4- مساحة مقطع حديد التسليح الرئيسى (-

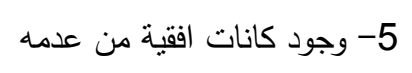

كذلك تم فى هذه الدراسة مقارنة مقاومة القص القصوى للكوابيل و التى تم الحصول عليها معمليا بتلك المحسوبة من المعادلات المقترحة بجانب معادلات الكود الأمريكى . و من اهم النتائج التى نم الحصول عليها فى هذا البحث ما يلى :

1. وجود الياف الصلب بالخلطة الخرسانية يحسن من سلوك الكوابيل القصيره فى القص من ناحية حمل

القص الأقصى و كذلك الممطولية .

2. فاعلية الألياف فى زيادة مقاومة القص القصوى للكوابيل القصيره يتتاقص مع وجود الكانات الافقية . 3. يظهر ايضا دور الألياف بوضوح فى زيادة كل من حمل القص الاقصى و الممطولية للكوابيل القصيره عندما تكون نسبة التسليح الرئيسى منخفضة او عندما يزيد نسبة بحر القص الى العمق الفعال للكابولى.

4. أظهرت نتائج مقارنة قيم مقاومة القص القصوى للكوابيل القصيرة الخرسانية المصنوعة من خرسانة عالية المقاومة تحتوى على الياف الصلب و التى تم الحصول عليها معمليا بتلك المحسوبه من المعادلات المنوفره ان معادلات نموذج 